\title{
Development and Validation of Liquid Chromatography-Tandem Mass Spectrometry Method for the Quantification of Ertapenem in Human Serum
}

Hee $\mathrm{KH}^{\mathbf{1}^{*}}$, Fisher $\mathrm{D}^{1}$, Tam $\mathbf{V H}^{2}$ and Soon-U Lee $\mathrm{L}^{1}$

${ }^{1}$ National University Health System, Singapore, Singapore

${ }^{2}$ University of Houston College of Pharmacy, Houston, Texas, USA

\begin{abstract}
We have developed and validated a liquid chromatography tandem mass spectrometry (LC-MS/MS) method for the quantification of ertapenem in serum samples derived from patients with complicated urinary tract infections. Ertapenem was separated on reverse phase C18 column within the analytical runtime of $2 \mathrm{~min}$. Detection and quantification of ertapenem was based on multiple reactions monitoring under positive ionization mode using deuterium-labeled internal standard. The lower limit of quantification of ertapenem in serum was $1 \mu \mathrm{g} / \mathrm{ml}$. Excellent linearity was demonstrated between $1-200 \mu \mathrm{g} / \mathrm{ml}$ in serum with $\mathrm{r} 2>0.996$. Accuracy and precision for the assay in serum were in the range of $96.7-106.5 \%$ and $0.59-4.22 \%$, respectively. The developed method is specific with no endogenous co-eluting peaks in serum. Minimal matrix effect was found in serum between 94.9-107.3\%. Ertapenem in serum was found stable at room temperature $\left(25^{\circ} \mathrm{C}\right)$ of up to $4 \mathrm{~h}$, in the autosampler $\left(6^{\circ} \mathrm{C}\right)$ of up to $20 \mathrm{~h}$ and at least three freeze-thaw cycles with recovered concentration of more than $97.1 \%$. This LC-MS/MS method is rapid, simple and provides sufficient sensitivity in measuring ertapenem concentration in serum samples derived from patients.
\end{abstract}

Keywords: LC-MS/MS; Ertapenem; Serum; Method validation; Pharmacokinetic

\section{Introduction}

Ertapenem is a 1 -methyl- $\beta$ carbapenem with broad antibacterial spectrum and long half-life of $4.5 \mathrm{~h}$ [1]. It has been developed as single daily dose carbapenem against a wide range of community-acquired infections [2].

Several methods of liquid chromatography coupled to either UV absorbance or mass spectrometry detection have been developed for the quantification of ertapenem in human plasma. The reported HPLCUV methods had long analytical time of more than 7 min by using either reverse phase or Penta Fluoro Phenyl column with injection volume of 10 to $50 \mu \mathrm{l}$ [3-6]. Ertapenem was detected and quantified at UV absorbance of $295 \mathrm{~nm}$. A LC-MS method was developed for the quantification of ertapenem in human plasma by detecting the deprotonated molecular ion of ertapenem under negative ionization mode with lower limit of quantification of 0.5 or $1 \mu \mathrm{g} / \mathrm{ml}$ and analytical run time of more than $5 \mathrm{~min}[7,8]$. In these cases, either meropenem or ceftazidime was used as internal standards in the quantification of ertapenem instead of deuterium-labeled ertapenem. LC-MS/MS methods have also been developed for the quantification of ertapenem on dried blood spot [9] and microdialysate [10].

Pharmacokinetics and pharmacodynamics of ertapenem have been studied in healthy volunteers [11], burns and critically ill patients $[12,13]$. An ertapenem assay for plasma pharmacokinetic study was reported but the methodology was poorly described [14]. We therefore sought to systematically develop and validate a rapid and sensitive LC-MS/MS method for the quantification of ertapenem in serum derived from patients with complicated urinary tract infections for pharmacokinetic study.

\section{Experimental}

\section{Reagent and materials}

Ertapenem and ertapenem- $d_{4}$ were purchased from Alsachim (Illkirch Graffenstaden, France). Formic acid (analytical grade) and 2-(-4morpholino)ethylsulfonic acid (MES) were purchased from Sigma Chemical Co. (St. Louis, MO, USA). Acetonitrile and methanol (both HPLC grade) were obtained from Merck (Darmstadt, Germany). Direct-QTM water (Millipore Milford, MA, USA) was used for the mobile phase preparation.

\section{Sample collection and preparation}

Blood samples were collected into blank tubes and centrifuged for 8 minutes at approximately $2,500 \times g$ at $4^{\circ} \mathrm{C}$. The serum samples (supernatant) were added with two parts volume of MES buffer $(0.1 \mathrm{M}$, $\mathrm{pH}$ 6.5) and stored at $-80^{\circ} \mathrm{C}$ prior to analysis. Ertapenem was extracted from the serum samples or calibration/quality control (QC) samples by means of protein precipitation. Briefly, $50 \mu \mathrm{l}$ of serum sample were extracted in $100 \mu \mathrm{l}$ of extraction solvent (acetonitrile: methanol, 1:1, $\mathrm{v} / \mathrm{v}$ ) containing the internal standard (ertapenem- $d_{4}$ at $2 \mu \mathrm{g} / \mathrm{ml}$ ). The mixture was vortexed thoroughly for protein precipitation followed by centrifugation at $13,000 \times g$ for $10 \mathrm{~min}$ [15]. Two microliter of the supernatant was injected to the LC-MS/MS system for analysis.

\section{Preparation of standard and calibration/QC samples}

Standard stock solutions of ertapenem and ertapenem- $d_{4}$ were prepared in methanol as 10 and $1 \mathrm{mg} / \mathrm{ml}$, respectively, and stored at $-20^{\circ} \mathrm{C}$. Highest calibration standards were prepared by spiking the ertapenem standard stock solution in blank serum. This was followed by serial dilution with blank serum of the highest calibration standard

*Corresponding author: Hee $\mathrm{KH}$, Department of Medicine, National University of Singapore, Singapore, Tel: + (65) 6601-1105; Fax: + (65) 6872-4130; E-mail: mdchkh@nus.edu.sg

Received March 11, 2015; Accepted April 12, 2015; Published April 20, 2015

Citation: Hee KH, Fisher D, Soon-U Lee L, Tam VH (2015) Development and Validation of Liquid Chromatography-Tandem Mass Spectrometry Method for the Quantification of Ertapenem in Human Serum. Pharm Anal Acta 6: 358 doi:10.4172/2153-2435.1000358

Copyright: ( $) 2015 \mathrm{Hee} \mathrm{KH}$, et al. This is an open-access article distributed unde the terms of the Creative Commons Attribution License, which permits unrestricted use, distribution, and reproduction in any medium, provided the original author and source are credited. 
Citation: Hee KH, Fisher D, Soon-U Lee L, Tam VH (2015) Development and Validation of Liquid Chromatography-Tandem Mass Spectrometry Method for the Quantification of Ertapenem in Human Serum. Pharm Anal Acta 6: 358. doi:10.4172/2153-2435.1000358

to obtain calibration ranges of $1-200 \mu \mathrm{g} / \mathrm{ml}$ in serum. For the QC samples, they were prepared at low, mid and high concentrations of the calibration curves which were 3,75 and $150 \mu \mathrm{g} / \mathrm{ml}$ in blank serum. Serum calibration/QC samples were added with two parts volume of MES buffer before analysis.

\section{UHPLC-MS/MS instrument and conditions}

The LC-MS/MS system consisted of Agilent 1290 UHPLC equipped with a cooled autosampler $\left(6^{\circ} \mathrm{C}\right)$ connected to Agilent 6460 triple quadrupole mass spectrometer (Agilent Technologies, Waldbronn, Germany). Ertapenem was separated on Zorbax Eclipse Plus $\mathrm{C}_{18}$ Rapid Resolution HD (Agilent Technologies, $50 \mathrm{~mm} \times 2.1 \mathrm{~mm}, 1.8$ $\mu \mathrm{m})$ with gradient elution. Mobile phase A and B were water and $90 \%$ $(\mathrm{v} / \mathrm{v})$ acetonitrile, respectively, both containing $0.1 \%$ formic acid, with flow rate of $0.5 \mathrm{ml} / \mathrm{min}$. The elution profile of mobile phase was set as followed: $0-0.5 \mathrm{~min}, 15 \% \mathrm{~B}$; $0.5-1.5 \mathrm{~min}, 15-90 \% \mathrm{~B} ; 1.5-2 \mathrm{~min}, 90 \% \mathrm{~B}$. There was $0.5 \mathrm{~min}$ of post time after each injection for the mobile phase to revert back to the initial $15 \% \mathrm{~B}$. The mass spectrometer was operated under positive ionization mode and the detection of the analytes was based on multiple-reaction monitoring of $\mathrm{m} / \mathrm{z} 476.2 \rightarrow 432.1$ and 480.2 $\rightarrow 436.1$ for ertapenem and ertapenem- $d_{4}$, respectively. The fragmentor and collision energy were set as $110 \mathrm{~V}$ and $2 \mathrm{eV}$, respectively. The source temperature, drying gas $\left(\mathrm{N}_{2}\right)$ flow rate, nebulizer pressure, sheath gas temperature, sheath gas flow rate and capillary voltage of the mass spectrometer were set at $300^{\circ} \mathrm{C}, 10 \mathrm{~L} / \mathrm{min}, 45 \mathrm{psi}, 300^{\circ} \mathrm{C}, 11 \mathrm{~L} /$ $\min$ and $5000 \mathrm{~V}$, respectively.

\section{Method validation}

The validation was carried out according to US FDA guidance for industry on bioanalytical method validation. Chromatograms were automatically integrated using MassHunter Workstation Software (Agilent Technologies Inc., Version B.04.00)

Calibration linearity and sample quantification: Calibration curves of ertapenem in serum were constructed using eight different calibration concentrations by MassHunter Quantitative software. Concentrations of ertapenem in the samples were back-calculated from the weighted $\left(1 / \mathrm{x}^{2}\right)$ linear least squares fitted lines of peak area ratio (ertapenem to internal standard ertapenem- $d_{4}$ ) versus concentrations. Linearity, expressed as coefficient of correlation $r^{2}$, was calculated using the software.

Accuracy and precision: Accuracy and precision were determined by quantification of the QC samples at lower limit of quantification (LLOQ), low, mid and high concentrations of the calibration curves. LLOQ was defined as the lowest concentration point of the calibration curve. Intraday variability was determined by analyzing five times the QC samples using the same calibration curve. Interday variability was determined by analyzing the QC samples on five different days using calibration curves constructed on the respective days. Accuracy was defined as the percentage of the calculated concentration, based on the calibration curves, deviated from the known concentration. Precisions were reported in coefficient of variance $(\mathrm{CV} \%=$ standard deviation/ mean $\times 100)$. The allowable intraday and interday accuracy and precision were $\pm 20 \%$ for LLOQs and $\pm 15 \%$ for all other concentrations.

Selectivity, matrix effect and extraction recovery: Six different batches of drug-free serum were prepared as blanks and spiked at the LLOQ level $(1 \mu \mathrm{g} / \mathrm{ml})$ of ertapenem to determine whether endogenous compounds of serum blanks interfere with the detection of the ertapenem and ertapenem- $d_{4}$. The area of co-eluting peaks in the blanks must not exceed $20 \%$ of that of ertapenem and ertapenem- $d_{4}$ at LLOQ.
Matrix effect (ME) and extraction recovery were evaluated at low, mid and high concentrations of ertapenem in serum. ME was determined by comparing the response of ertapenem spiked in serum extract with that of neat standard at equivalent concentration. Whereas, extraction recovery was determined by comparing the response of ertapenem spiked in serum with that of serum extract at equivalent concentration.

Stability: Stability was assessed in QC samples at low, mid and high concentrations of ertapenem in serum. Room temperature, post-preparative and freeze-thaw stability were defined as the mean recovered concentration (\%) after $4 \mathrm{~h}$ storage at room temperature $\left(25^{\circ} \mathrm{C}\right), 20 \mathrm{~h}$ storage in autosampler $\left(6^{\circ} \mathrm{C}\right)$ and three cycles of freethawing (with at least $24 \mathrm{~h}$ of frozen time at $-80^{\circ} \mathrm{C}$ in between sample thawing), respectively.

\section{Method application}

The developed and validated method was used to determine ertapenem concentrations in samples obtained from patients with complicated urinary tract infections in a prospective, open-label, observational, pharmacokinetic study. Ten adult patients (age 21-80) with normal renal function or mild renal impairment (creatinine clearance $>30 \mathrm{ml} / \mathrm{min}$ ), diagnosed with complicated urinary tract infection were enrolled. Ertapenem was administered as intravenous infusion of 1 g over $30 \mathrm{~min}$. One blood sample was collected immediately prior to drug administration and three blood samples were taken at 2, 10 and $23.5 \mathrm{~h}$ after the end of drug infusion for quantification of ertapenem.

\section{Results and Discussion}

\section{LC-MS/MS optimization}

To the best of your knowledge, we are the first to systematically report the method development and validation for the quantification of ertapenem in human serum using deuterium-labeled ertapenem as internal standard. The LC method developed was rapid with analytical run time of $2 \mathrm{~min}$ and post time of $0.5 \mathrm{~min}$. Therefore, 24 samples were analyzed in an hour. Ertapenem was eluted during the gradient elution of mobile phase with retention time of $1.04 \mathrm{~min}$. Both ertapenem and ertapenem- $d_{4}$ formed protonated molecules of $[\mathrm{M}+\mathrm{H}]^{+}$when the MS was operated under positive ionization mode. Upon fragmentation, the most abundant product ion was chosen as the quantitative ion in the determination of MRM transition. The product ion spectra of ertapenem and ertapenem- $d_{4}$ are shown in Figures $1 \mathrm{~A}$ and $1 \mathrm{~B}$, respectively. Signals of ertapenem and internal standard were acquired during the MRM time segment of 0.8-2 min with the rest of the elution being diverted to waste.

\section{Calibration linearity, accuracy, precision}

Calibration curves of response ratio (ertapenem to ertapenem- $d_{4}$ ) versus ertapenem concentrations exhibited excellent linearity with $r^{2>} 0.996$ using weighting of $1 / \mathrm{x}^{2}$ for serum in the range of $1-200 \mu \mathrm{g} / \mathrm{ml}$. Accuracy and precision of the developed method in serum have passed the requirement of FDA guidance for bioanalytical method validation. Accuracy and precision, evaluated at LLOQ, low, mid and high QC concentrations for both intraday and interday, ranged between 96.7106.5 and $0.59-4.22 \%$, respectively (Table 1 ).

\section{Selectivity, matrix effect and extraction recovery}

Extracted chromatograms of ertapenem at LLOQ and ertapenem- $d$ are shown in Figures $2 \mathrm{~A}$ and 2C, respectively. Ertapenem peak at 
(A)

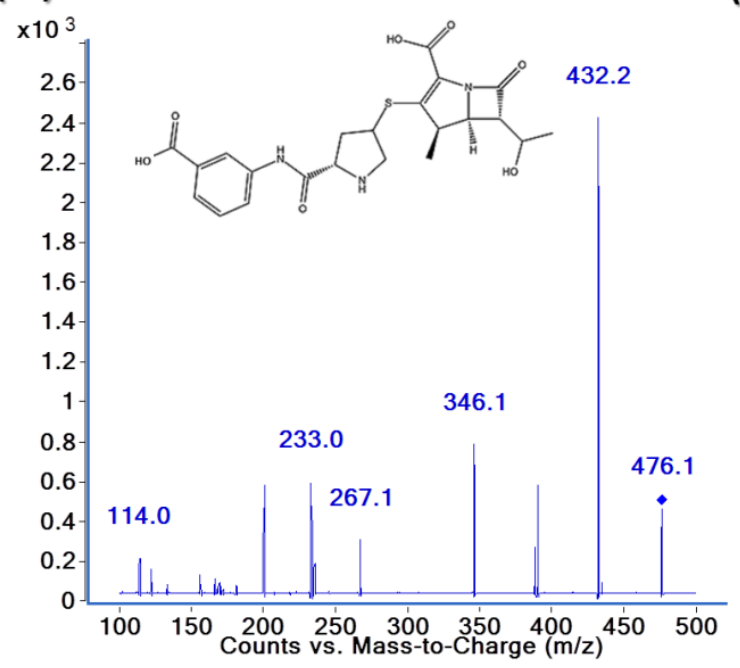

(B)

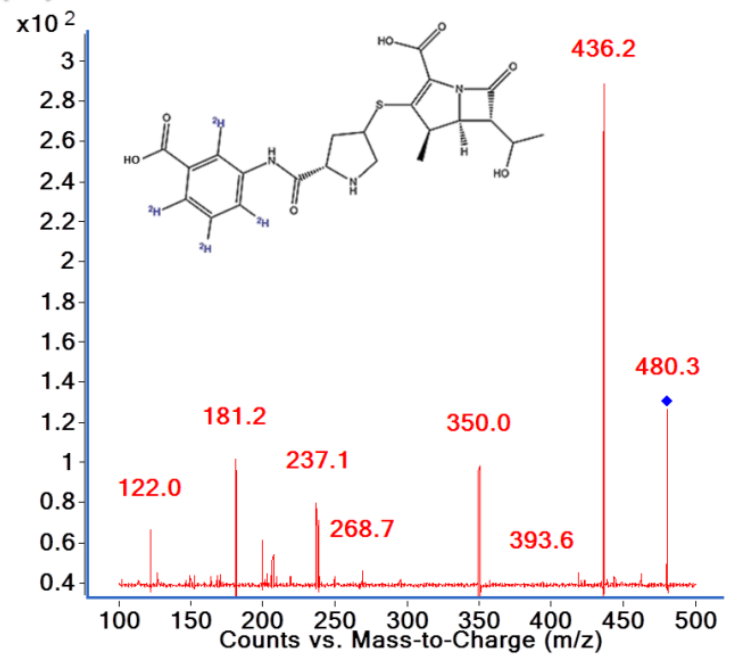

Figure 1: Product ion spectra of ertapenem (A) and internal standard ertapenem- $d_{4}(\mathrm{~B})$

(A)

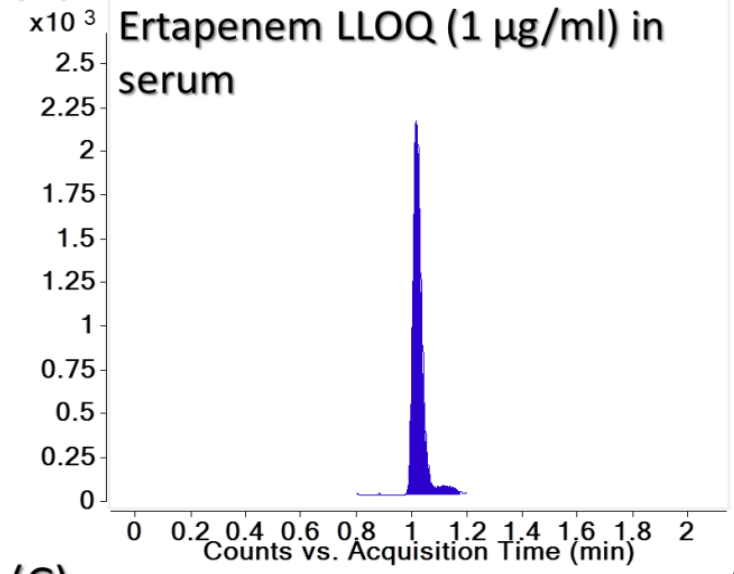

(C)

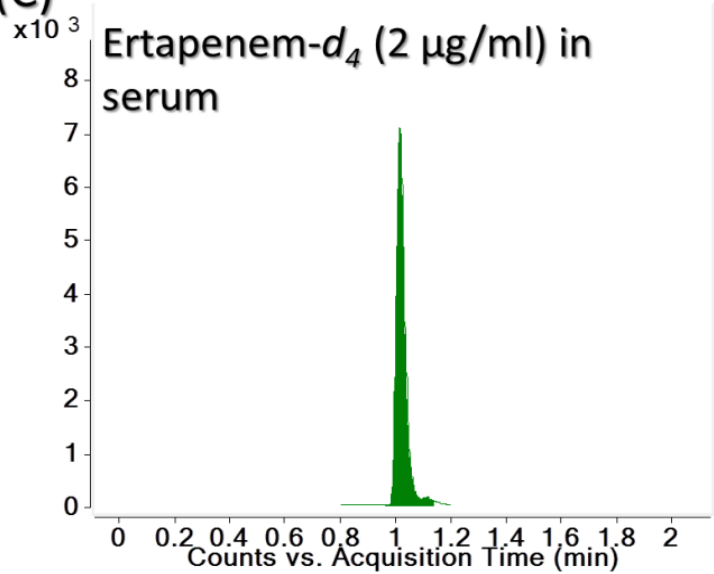

(B)

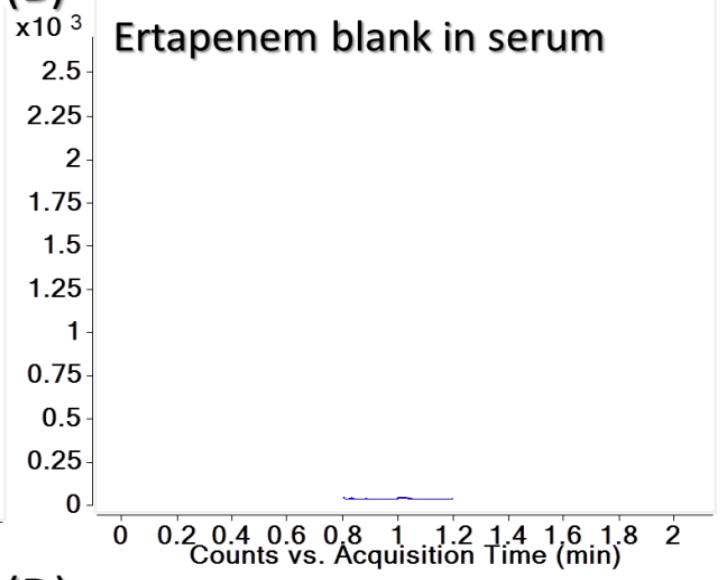

(D)

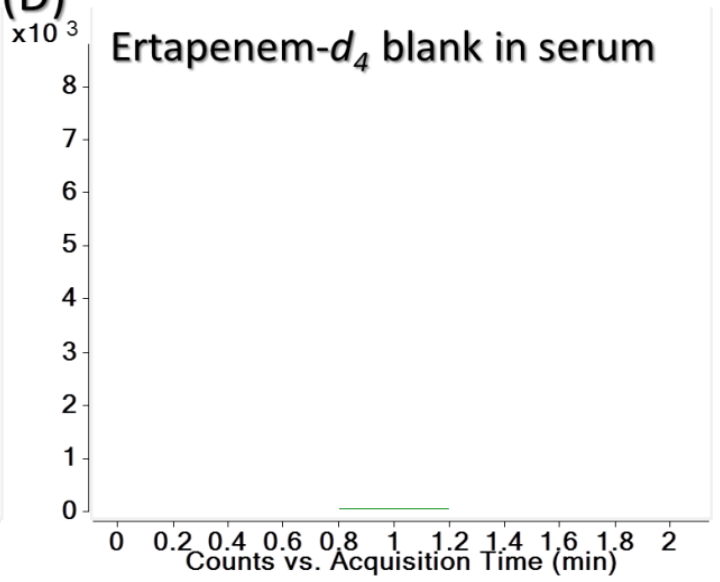

Figure 2: Extracted chromatograms of ertapenem $(A)$ and ertapenem- $d_{4}(C)$ and their blanks (B and D, respectively) in serum. 
Citation: Hee KH, Fisher D, Soon-U Lee L, Tam VH (2015) Development and Validation of Liquid Chromatography-Tandem Mass Spectrometry Method for the Quantification of Ertapenem in Human Serum. Pharm Anal Acta 6: 358. doi:10.4172/2153-2435.1000358

Page 4 of 5

LLOQ in serum had signal-to-noise ratio of $>10$. The developed method is selective as no endogenous peaks were found to co-elute with ertapenem and ertapenem- $d_{4}$ in serum (Figures 2B and 2D). Minimal $\mathrm{ME}$ on ertapenem was found in serum in the range of $94.9-107.3 \%$ when evaluated at low, mid and high QC concentrations (Table 2). Ertapenem extraction recovery in serum was found to be excellent and reproducible (Table 2).

\section{Stability}

Ertapenem was stabilized In MES buffer of $\mathrm{pH} 6.5$ during serum sample collection as well as in the preparation of calibration/QC samples. Ertapenem in serum was found stable at room temperature and $6^{\circ} \mathrm{C}$ for up to 4 and $20 \mathrm{~h}$, respectively, with minimum recovered concentration of $97.1 \%$. It was also found stable for at least three freezethaw cycles with minimum recovered concentration of $97.3 \%$.

\section{Application}

Our developed and validated method provided sufficient sensitivity and was successfully applied to measuring serum ertapenem concentrations in patients with complicated urinary tract infection [16]. Representative chromatograms of serum ertapenem at preIV, 2, 10 and $23.5 \mathrm{~h}$ post-IV of a patient are shown in Figure 3. Pharmacokinetic curves of 5 patients are shown in Figure 4. Highest ertapenem concentration was found at $2 \mathrm{~h}$ post-IV which was then gradually decreased to $23.5 \mathrm{~h}$.

\section{Conclusion}

We have developed and validated an accurate and precise LCMS/MS method for the quantification of ertapenem in human serum. The method is rapid and simpler than previously reported methods. The developed method provides sufficient sensitivity for measuring serum ertapenem in patients with complicated urinary tract infection receiving IV ertapenem $1 \mathrm{~g}$.

\begin{tabular}{|c|c|c|c|c|c|c|}
\hline \multirow[b]{2}{*}{$\begin{array}{l}\text { Nominal conc. ( } \mu \mathrm{g} / \\
\mathrm{ml})\end{array}$} & \multicolumn{3}{|c|}{ Intraday $(n=5)$} & \multicolumn{3}{|c|}{ Interday (n=5) } \\
\hline & $\begin{array}{l}\text { Found conc. } \\
\text { (mean } \pm \text { SD) }\end{array}$ & Accuracy (\%) & $\begin{array}{c}\text { Precision } \\
\text { (\%CV) }\end{array}$ & $\begin{array}{l}\text { Found conc. } \\
\text { (mean } \pm \text { SD) }\end{array}$ & Accuracy (\%) & $\begin{array}{c}\text { Precision } \\
\text { (\%CV) }\end{array}$ \\
\hline 1 & $0.98 \pm 0.02$ & 97.94 & 1.96 & $0.98 \pm 0.03$ & 97.87 & 3.23 \\
\hline 3 & $3.12 \pm 0.04$ & 103.93 & 1.42 & $3.20 \pm 0.07$ & 106.54 & 2.07 \\
\hline 75 & $75.08 \pm 1.16$ & 100.11 & 1.55 & $77.20 \pm 3.26$ & 102.93 & 4.22 \\
\hline 150 & $146 \pm 0.9$ & 97.50 & 0.59 & $145 \pm 3.1$ & 96.73 & 2.13 \\
\hline
\end{tabular}

Table 1: Intraday and interday accuracy and precision of ertapenem in serum.

\begin{tabular}{|c|c|c|c|c|c|c|}
\hline \multirow{2}{*}{$\begin{array}{l}\text { Nominal conc. } \\
\qquad(\mathrm{ng} / \mathrm{ml})\end{array}$} & \multicolumn{3}{|c|}{ Mean peak area of standard $\left(\times 10^{4}\right)(n=6)$} & \multicolumn{2}{|c|}{ Extraction recovery } & \multirow{2}{*}{ Matrix effect } \\
\hline & neat & $\begin{array}{c}\text { spiked in serum } \\
\text { extract }\end{array}$ & spiked in serum & Mean (\%) & CV (\%) & \\
\hline 3 & 1.26 & 1.20 & 1.23 & 102.77 & 1.09 & 94.90 \\
\hline 75 & 27.66 & 28.09 & 29.10 & 103.58 & 1.40 & 101.57 \\
\hline 150 & 48.16 & 51.68 & 53.39 & 103.34 & 2.16 & 107.31 \\
\hline
\end{tabular}

Table 2: Matrix effect and extraction recovery of ertapenem in serum at low, mid and high QC concentrations.
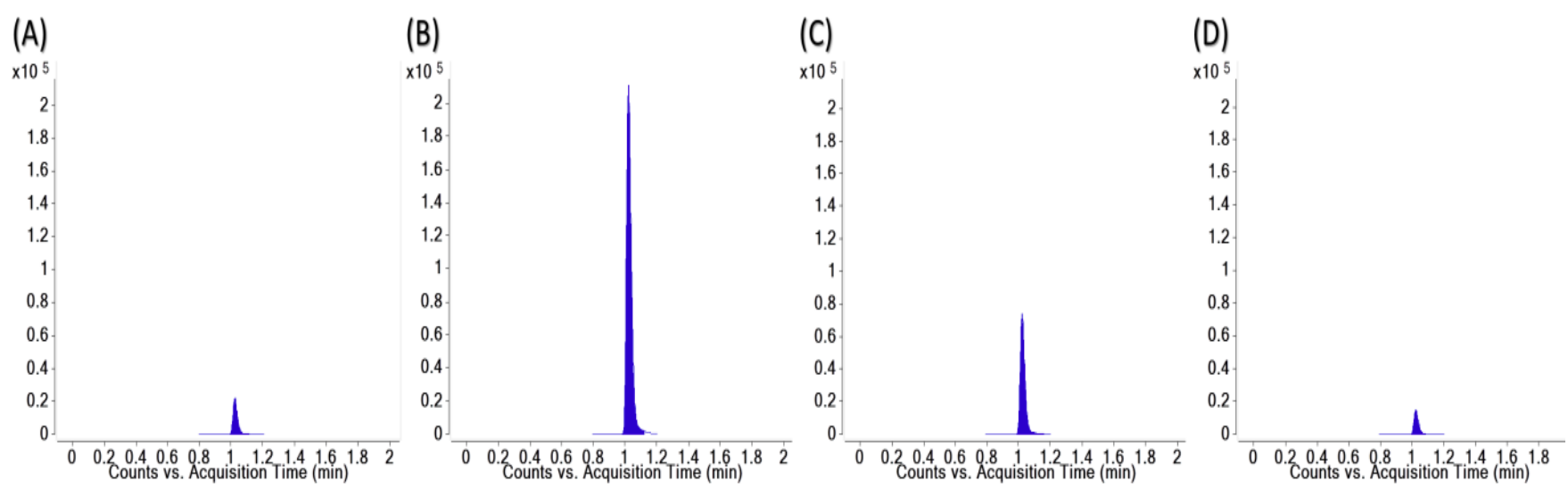

Figure 3: Representative chromatograms of ertapenem in serum samples at pre-IV (A), 2 (B), 10 (C) and $23.5 \mathrm{~h}$ (D) post-IV. 
Citation: Hee KH, Fisher D, Soon-U Lee L, Tam VH (2015) Development and Validation of Liquid Chromatography-Tandem Mass Spectrometry Method for the Quantification of Ertapenem in Human Serum. Pharm Anal Acta 6: 358. doi:10.4172/2153-2435.1000358

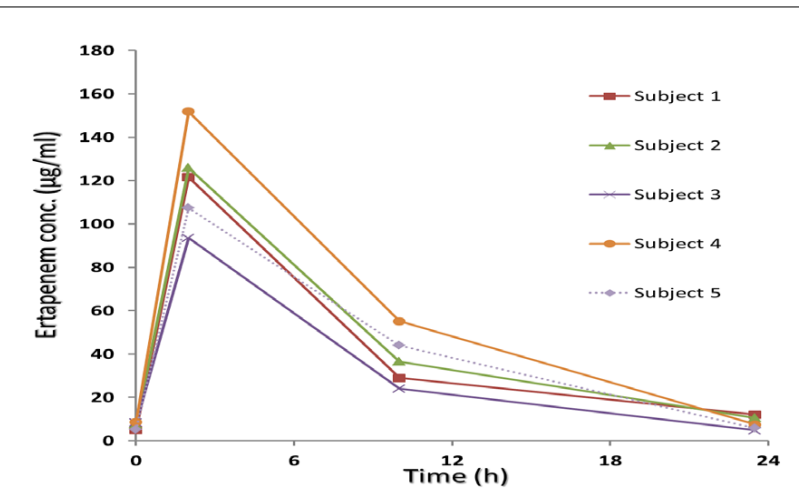

Figure 4: Pharmacokinetic curves of serum ertapenem derived from patients with complicated urinary tract infection.

\section{References}

1. Odenholt I (2001) Ertapenem: a new carbapenem. Expert Opin Investig Drugs 10: 1157-1166.

2. Seaton RA, Barr DA (2013) Outpatient parenteral antibiotic therapy: principles and practice. Eur J Intern Med 24: 617-623.

3. Dailly E, Bouquie R, Deslandes G, Jolliet P, Le Floch R (2011) A liquid chromatography assay for a quantification of doripenem, ertapenem, imipenem, meropenem concentrations in human plasma: application to a clinical pharmacokinetic study. J Chromatogr B Analyt Technol Biomed Life Sci 879: 1137-1142.

4. Mundkowski RG, Majcher-Peszynska J, Burkhardt O, Welte T, Drewelow B (2006) A new simple HPLC assay for the quantification of ertapenem in human plasma, lung tissue, and broncho-alveolar lavage fluid. J Chromatogr B Analyt Technol Biomed Life Sci 832: 231-235.

5. McWhinney BC, Wallis SC, Hillister T, Roberts JA, Lipman J, et al. (2010) Analysis of 12 beta-lactam antibiotics in human plasma by HPLC with ultraviole detection. J Chromatogr B Analyt Technol Biomed Life Sci 878: 2039-2043.
6. Legrand T, Chhun S, Rey E, Blanchet B, Zahar JR, et al. (2008) Simultaneous determination of three carbapenem antibiotics in plasma by HPLC with ultraviolet detection. J Chromatogr B Analyt Technol Biomed Life Sci 875: 551 556.

7. Koal T, Deters M, Resch K, Kaever V (2006) Quantification of the carbapenem antibiotic ertapenem in human plasma by a validated liquid chromatographymass spectrometry method. Clin Chim Acta 364: 239-245.

8. Pickering M, Brown S (2013) Quantification and validation of HPLC-UV and LC-MS assays for therapeutic drug monitoring of ertapenem in human plasma. Biomed Chromatogr: BMC 27: 568-574.

9. la Marca G, Giocaliere E, Villanelli F, Malvagia S, Funghini S, et al. (2012) Development of an UPLC-MS/MS method for the determination of antibiotic ertapenem on dried blood spots. J Pharm Biomed Anal 61: 108-113.

10. Lefeuvre S, Venisse N, Marchand S, Bachelet M, Couet W (2008) A simple and sensitive liquid chromatography-tandem mass spectrometry assay for the quantification of ertapenem in microdialysate. J Chromatogr B Analyt Technol Biomed Life Sci 862: 242-245.

11. Nix DE, Majumdar AK, DiNubile MJ (2004) Pharmacokinetics and pharmacodynamics of ertapenem: an overview for clinicians. J Antimicrob Chemother 53 Suppl 2: ii23-28.

12. Dailly E, Arnould JF, Fraissinet F, Naux E, Letard de la Bouraliere MA, et al. (2013) Pharmacokinetics of ertapenem in burns patients. Int J Antimicrob Agents 42: 48-52.

13. BrinkAJ, Richards GA, Schillack V, Kiem S, Schentag J (2009) Pharmacokinetics of once-daily dosing of ertapenem in critically ill patients with severe sepsis. Int J Antimicrob Agents 33: 432-436.

14. Pletz MW, Rau M, Bulitta J, De Roux A, Burkhardt O, et al. (2004) Ertapenem pharmacokinetics and impact on intestinal microflora, in comparison to those of ceftriaxone, after multiple dosing in male and female volunteers. Antimicrob Agents Chemother 48: 3765-3772.

15. Vadlapudi AD, Vadlapatla RK, Kwatra D, Earla R, Samanta SK, et al. (2012) Targeted lipid based drug conjugates: a novel strategy for drug delivery. Int $J$ Pharm 434: 315-324.

16. Zhou J, Sulaiman Z, Llorin RM, Hee KH, Lee LS, et al. (2014) Pharmacokinetics of ertapenem in outpatients with complicated urinary tract infections. Antimicrob Chemother 69: 2517-2521. 